PAwee Lipowski*

\title{
REALIZACJA SZCZEPIEŃ OCHRONNYCH - IMPLIKACJE PRAWNE
}

\section{Wstęp}

Należy przyjąć, że celem obowiązującego w Polsce systemu obowiązkowych szczepień ochronnych jest zapewnienie bezpieczeństwa zdrowotnego zarówno osób poddawanych szczepieniu, jak i całej populacji. Tak rozumiane bezpieczeństwo zdrowotne - w wymiarze jednostkowym i zbiorowym, staje się wówczas podstawową kategorią zdrowia publicznego. Na polski system szczepień ochronnych składają się zarówno przyjmowane w prawodawstwie krajowym warunki zakupu szczepionek oraz standardy ich dostaw i przechowywania - jako domeny odpowiedzialności władz publicznych, jak i warunki, w jakich podaje się konkretną szczepionkę pacjentowi - jako obszaru odpowiedzialności świadczeniodawcy in concreto (zwłaszcza personelu medycznego). Ten ostatni obszar odpowiedzialności ma szczególne znaczenie dla minimalizacji ryzyka wystąpienia tzw. niepożądanych odczynów poszczepiennych, mających istotny wpływ na kształtowanie się postaw pacjentów (obywateli) aprobujących lub negujących obowiązkowe szczepienia ochronne. Dotyczy to przede wszystkim, często manifestowanych publicznie, indywidualnych postaw rodziców względem szczepień dzieci.

* Dr, Zakład Polityki Zdrowotnej i Zarządzania, Instytut Zdrowia Publicznego, Wydział Nauk o Zdrowiu, Collegium Medicum Uniwersytetu Jagiellońskiego. 
Warto przy tym zaznaczyć, że szczepienia mogą być realizowane zarówno jako obowiązkowe, jak i dobrowolne, a ich bezpieczeństwo stosowania w każdym przypadku powinno być równie wysokie.

Szczegółowe omówienie kwestii odpowiedzialności władz publicznych związanej z rozumianym sensu largo zapewnieniem obywatelom szczepionek pozostanie poza zakresem prezentowanych rozważań z uwagi na przyjęte ramy niniejszego opracowania. Warto przy tym wskazać, że zagadnienie to ma szczególne znaczenie w obszarze zdrowia publicznego i zadań administracji publicznej w tym zakresie.

Mając na uwadze w ten sposób definiowane bezpieczeństwo zdrowotne, wyrazem prawnych gwarancji bezpieczeństwa dla pacjenta (obywatela), w jego różnych i codziennych relacjach społecznych, powinny być $\mathrm{w}$ szczególności podejmowane przez organy administracji publicznej działania egzekucyjne wobec osób uchylających się od wykonywania obowiązkowych szczepień ochronnych. Skuteczność takich działań, połączona oczywiście z ich adekwatnością w sytuacji konkretnego pacjenta, warunkowanej przede wszystkim jego stanem zdrowia, ma szczególne znaczenie przy wpływaniu na aktualnie obserwowane postawy społeczne osób niechętnie odnoszących się do szczepień ochronnych (zwłaszcza wykonywanych u dzieci). Charakterystyce tego zagadnienia, z punktu widzenia praktycznych implikacji płynących dla pacjenta z obowiązujących przepisów prawnych, jak i wybranego orzecznictwa sądowego, poświęcony będzie niniejszy artykuł.

\section{Prawna regulacja obowiązkowych szczepień ochronnych - wybrane regulacje}

Zgodnie z nadrzędną regulacją prawną $\mathrm{w}$ dziedzinie zdrowia publicznego - art. 68 ust. 4 Konstytucji Rzeczypospolitej Polskiej z dnia 2 kwietnia 1997 r., obowiązkiem władz publicznych jest m.in. zwalczanie chorób epidemicznych ${ }^{1}$. W tym celu w Polsce utrzymywany jest obowiązek szczepień ochronnych, adresowany do całej populacji kraju. Jego podsta-

${ }^{1}$ Konstytucja Rzeczpospolitej Polskiej z dnia 2 kwietnia 1997 r., Dz.U. Nr 78, poz. 483 z późn. zm. Zgodnie z przywołanym przepisem: „władze publiczne są obowiązane do zwalczania chorób epidemicznych i zapobiegania negatywnym dla zdrowia skutkom degradacji środowiska". 
wą normatywną jest ustawa z dnia 5 grudnia 2008 r. o zapobieganiu oraz zwalczaniu zakażeń i chorób zakaźnych u ludzi².

Mając na uwadze podstawowe zadanie każdego szczepienia ochronnego, jakim jest wytwarzanie odporności na zakaźne czynniki chorobotwórcze, oprócz obowiązkowych szczepień ochronnych, minister właściwy do spraw zdrowia, w ramach przyjętego w Polsce systemu szczepień, określa także, na podstawie ww. ustawy, wykaz zalecanych szczepień ochronnych ${ }^{3}$.

Z punktu widzenia systemu zdrowotnego i przyjętego w Polsce obowiązującego modelu powszechnego ubezpieczenia zdrowotnego szczepienie ochronne możemy uznać za rodzaj działania profilaktycznego, zaliczanego do świadczeń na rzecz zachowania zdrowia, zapobiegania chorobom i wczesnego wykrywania chorób (zgodnie z art. 27 ust. 1 pkt 7 ustawy z dnia 27 sierpnia 2004 r. o świadczeniach opieki zdrowotnej finansowanych ze środków publicznych ${ }^{4}$ ).

Stosownie do art. 5 ust. 1 pkt 1 lit b) ww. obowiązkowym szczepieniom ochronnym podlega każda osoba przebywająca na terytorium Rzeczpospolitej Polskiej (bez względu na posiadany tytuł do otrzymania świadczeń zdrowotnych w systemie zdrowotnym) ${ }^{5}$.

W tym kontekście warto zwrócić uwagę na niedawny i ważny wyrok Wojewódzkiego Sądu Administracyjnego w Warszawie z dnia 10 lutego 2017 r., zgodnie z którym m.in. ustawowy obowiązek szczepień ochron-

${ }^{2}$ Dz.U. z 2016 r. poz. 1866 z późn. zm.; dalej: ustawa o zapobieganiu i zwalczaniu zakażeń. Ustawa weszła w życie z dniem 1 stycznia 2009 r., uchylając wcześniej obowiązującą ustawę z dnia 6 września 2001 r. o chorobach zakaźnych i zakażeniach (tekst pierwotny: Dz.U. Nr 126, poz. 1384). Druga ze wskazanych ustaw zmieniła w sposób istotny system zwalczania chorób zakaźnych statuowany na podstawie dekretu z dnia 16 kwietnia $1946 \mathrm{r}$. o zwalczaniu chorób wenerycznych oraz ustawy z dnia 13 listopada 1963 r. o zwalczaniu chorób zakaźnych.

${ }^{3}$ Obecnie obowiązuje w tym zakresie rozporządzenie Ministra Zdrowia z dnia 16 września 2010 r. w sprawie wykazu zalecanych szczepień ochronnych oraz sposobu finansowania i dokumentowania zalecanych szczepień ochronnych wymaganych międzynarodowymi przepisami zdrowotnymi (Dz.U. Nr 180, poz. 1215), wydane na podstawie art. 19 ust. 10 ustawy o zapobieganiu i zwalczaniu zakażeń.

${ }^{4}$ Dz.U. z 2016 r. poz. 1793 z późn. zm. Zgodnie ze wskazanym przepisem: „świadczenia na rzecz zachowania zdrowia, zapobiegania chorobom i wczesnego wykrywania chorób obejmują wykonywanie szczepień ochronnych". Przywołana ustawa stanowi sui generis konstytucję systemu ochrony zdrowia w Polsce.

${ }^{5}$ Zgodnie z powołanym przepisem: „osoby przebywające na terytorium Rzeczypospolitej Polskiej są obowiązane na zasadach określonych w ustawie (o zapobieganiu i zwalczaniu zakażeń - przyp. aut.) do poddawania się szczepieniom ochronnym". 
nych oznacza niedopuszczalność korzystania z tzw. klauzuli sumienia, tj. uprawnienia pacjenta do odmowy poddania się świadczeniu zdrowotnemu z powołaniem się na art. 16 ustawy z 2008 r. o prawach pacjenta i Rzeczniku Praw Pacjenta. Obowiązek poddania się przymusowym szczepieniom ochronnym oznacza również obowiązek poddania się lekarskim badaniom kwalifikacyjnym w celu wykluczenia przeciwwskazań do wykonania obowiązkowego szczepienia ochronnego, na podstawie art. 17 ust. 2 ustawy o zapobieganiu i zwalczaniu zakażeń 6 .

Wskazany Sąd wyraził tym samym w swoim orzeczeniu, jak istotna jest wartość ochrony bezpieczeństwa zdrowotnego populacji, mająca w tych warunkach pierwszeństwo przed ideą każdorazowej zgody pacjenta (lub braku takiej zgody) na udzielenie mu danego świadczenia zdrowotnego (jako wyrazu wolności osoby ludzkiej). Takimi świadczeniami, w ramach „procesu” szczepienia ochronnego (udzielanie świadczeń zdrowotnych), będą zarówno samo podanie szczepionki, jak i poprzedzające je lekarskie badanie kwalifikacyjne.

Podkreślić należy, że odpowiedzialnymi za wypełnienie tego obowiązku, w przypadku osób nieposiadających pełnej zdolności do czynności prawnych (w szczególności dzieci), są osoby sprawujące nad nimi opiekę (najczęściej rodzice).

Dopełniając charakterystyki prawnej regulacji szczepień, należy wskazać, że aktualnie zawarty w ustawie o zapobieganiu i zwalczaniu zakażeń wykaz chorób zakaźnych i zakażeń obejmuje 57 pozycji (w tym 13 chorób zakaźnych objętych szczepieniami ochronnymi). Celem realizacji zadań państwa w tym obszarze Główny Inspektor Sanitarny, jako centralny organ administracji rządowej, realizujący zadania z zakresu zdrowia publicznego, określa program szczepień ochronnych na dany rok. Program ten wskazuje m.in., jakie szczepienia, w jakim okresie muszą być wykonane, a także kryteria określające populację objętą tymi szczepieniami ${ }^{7}$.

${ }^{6}$ Sygn. akt: VII SA/Wa 819/16 (LEX nr 2252052). W tezie wyroku przywołana jest ustawa z dnia 6 listopada 2008 r. o prawach pacjenta i Rzeczniku Praw Pacjenta, Dz.U. z 2017 r. poz. 1318 z późn. zm., dalej: ustawa o prawach pacjenta. Przepis art. 16 ustawy o prawach pacjenta statuuje prawo pacjenta do wyrażenia zgody na udzielenie określonych świadczeń zdrowotnych lub odmowy takiej zgody po uzyskaniu przez niego informacji o jego stanie zdrowia.

7 Obecnie obowiązujący Program Szczepień Ochronnych został wprowadzony komunikatem Głównego Inspektora Sanitarnego z dnia 4 stycznia 2017 r., wydanym na podstawie art. 17 ust. 11 ustawy o zapobieganiu i zwalczaniu zakażeń, Dz.Urz. M.Z., poz. 1. 
Mając na uwadze szczególne znaczenie szczepień ochronnych dzieci, wskazać należy, że lekarz sprawujący profilaktyczną opiekę zdrowotną (lekarz rodzinny) ma ważne zadania w zakresie edukacji i promocji szczepień. Obowiązany jest on bowiem do powiadomienia opiekunów prawnych (rodziców) o obowiązku przeprowadzenia szczepień ochronnych (np. podczas ich wizyty $\mathrm{w}$ gabinecie lub telefonicznie) oraz o szczepieniach zalecanych (nieobowiązkowych), także ze względu na "kondycję zdrowotną" dziecka (także np. wcześniaka). Z kolei przed wykonaniem szczepienia lekarz ten ma obowiązek przeprowadzenia badania kwalifikacyjnego mającego na celu wykluczenie istnienia przeciwskazań do podania danej szczepionki (warunkowanego przede wszystkim aktualnym stanem zdrowia dziecka). W przypadku stwierdzenia podstaw do odroczenia obowiązkowego szczepienia ochronnego lekarz wykonujący tego rodzaju badanie kwalifikacyjne powinien skierować pacjenta na konsultację specjalistyczną (pediatryczną) celem zapewnienia mu adekwatnej opieki medycznej.

Jak sygnalizowano już wyżej, odpowiedzialność za realizację obowiązku szczepień ochronnych dzieci ponosi, stosownie do art. 5 ust. 2 ustawy o zapobieganiu i zwalczaniu zakażeń, osoba, która sprawuje prawną pieczę nad osobą małoletnią lub bezradną (rodzic), albo opiekun faktyczny w rozumieniu art. 3 ust. 1 pkt 1 ustawy o prawach pacjenta ${ }^{8}$.

Dodać należy, że koszty szczepionek i przeprowadzenia szczepień finansowane są ze środków publicznych. Zakup szczepionek finansowany jest z budżetu państwa (w części, której tzw. dysponentem jest minister właściwy do spraw zdrowia), a więc poza środkami z systemu powszechnego ubezpieczenia zdrowotnego (realizowanego przez Narodowy Fundusz Zdrowia). Natomiast koszt przeprowadzenia szczepienia (usługi medycznej) objęty jest najczęściej wynagrodzeniem ryczałtowym stosowanym w podstawowej opiece zdrowotnej, w ramach powszechnego ubezpieczenia zdrowotnego. Wyjątkiem jest sytuacja, gdy dziecku na wniosek rodzica zostanie podana szczepionka inna niż zakupiona przez ministra zdrowia (np. w przypadku wyboru tzw. szczepionek poliwalentnych). W takiej sytuacji opiekun pokrywa koszt zakupu szczepionki, natomiast wykonanie "samego" szczepienia jest finansowane ze środków publicznych (w ramach systemu ubezpieczenia zdrowotnego).

8 Zgodnie z tym przepisem (definicją legalną) za "opiekuna faktycznego" uznaje się „osobę sprawująca, bez obowiązku ustawowego, stałą opiekę nad pacjentem, który ze względu na wiek, stan zdrowia albo stan psychiczny opieki takiej wymaga". 
Reasumując zagadnienie prawnych gwarancji szczepień, należy wskazać, że nadzór nad prawidłowym wykonywaniem szczepień ochronnych sprawuje właściwy powiatowy państwowy inspektor sanitarny działający w ramach struktur Państwowej Inspekcji Sanitarnej (jako organ tzw. rządowej administracji zespolonej w powiecie) $)^{9}$. Jest on również odpowiedzialny za dystrybucję szczepionek do świadczeniodawców wykonujących obowiązkowe szczepienia ochronne, zakupionych centralnie przez ministra zdrowia.

Dopełnieniem tego systemu jest nadzór nad niepożądanymi odczynami poszczepiennymi, implicite związanymi z wykonywaniem szczepień ochronnych, który powinien być wykonywany w trybie rozporządzenia Ministra Zdrowia z dnia 21 grudnia 2010 r. w sprawie niepożądanych odczynów poszczepiennych oraz kryteriów ich rozpoznawania ${ }^{10}$. Nadzór ten ma kluczowe znaczenie szczególnie w przypadku bezpośredniego zagrożenia życia osoby poddawanej szczepieniu (dziecka), klasyfikowanej jako tzw. ciężki niepożądany odczyn zapalny, i dlatego wymaga podejmowania natychmiastowych działań zarówno przez świadczeniodawcę, jak i (następczo) przez organy administracji publicznej państwa (Państwowa Inspekcja Sanitarna i minister właściwy do spraw zdrowia) ${ }^{11}$.

\section{Prawna regulacja działań egzekucyjnych w przypadku uchylania się od obowiązkowych szczepień ochronnych}

Zgodnie z art. 5 ustawy o Państwowej Inspekcji Sanitarnej do zakresu działania tej Inspekcji, w dziedzinie zapobiegania i zwalczania chorób, należy ustalanie zakresów i terminów szczepień ochronnych oraz sprawowanie nadzoru w tym zakresie. Organy Państwowej Inspekcji Sanitarnej mają zatem kluczowe znaczenie w zakresie zapewnienia bezpieczeństwa zdrowotnego obywateli $\mathrm{w}$ analizowanej dziedzinie szczepień. Bezpie-

${ }^{9}$ Działającej na podstawie ustawy z dnia 14 marca 1985 r. o Państwowej Inspekcji Sanitarnej, Dz.U. z 2017 r. poz. 1261.

${ }_{10}$ Dz.U. Nr 254, poz. 1711. Rozporządzenie to zostało wydane na podstawie art. 21 ust. 8 ustawy o zapobieganiu i zwalczaniu zakażeń.

${ }_{11}$ Więcej o zagadnieniu nadzoru w dziedzinie administracji publicznej: M. Wierzbowski (red.), Prawo administracyjne, wyd. 13, Warszawa 2017, s. 81 n.; Z. Leoński Materialne prawo administracyjne, wyd. 9, Warszawa 2009, s. 210-222. 
czeństwa ujmowanego $\mathrm{w}$ tym przypadku jako ochrona interesu prawnego członków populacji w postaci, jakkolwiek pojmowanego jednostkowo, zdrowia i życia.

Przyjęty sposób egzekwowania obowiązku szczepień, będącego obowiązkiem o charakterze niepieniężnym (definiowanym par excellence jako konieczność zachowania się przez pacjenta zgodnego z prawem, tj. poddania się przymusowemu szczepieniu realizowanemu przez personel medyczny), uregulowany jest w ustawie z dnia 17 czerwca 1966 r. o postępowaniu egzekucyjnym $\mathrm{w}$ administracji ${ }^{12}$.

Zgodnie z art. $5 \S 1$ pkt 2 tej ustawy uprawnionym do żądania wykonania $\mathrm{w}$ drodze egzekucji administracyjnej obowiązku szczepienia ochronnego, jako obowiązku wynikającego bezpośrednio z przepisów prawa (względnie z orzeczenia sądu lub innego organu - o czym dalej), jest organ Państwowej Inspekcji Sanitarnej (jako organ zarówno bezpośrednio zainteresowany $\mathrm{w}$ wykonaniu przez pacjenta obowiązku, jak i powołany do czuwania nad wykonaniem tego obowiązku). Tak więc organy Państwowej Inspekcji Sanitarnej są każdorazowo podmiotami uprawnionymi do żądania wykonania w drodze egzekucji administracyjnej obowiązku szczepień, tj. są wierzycielem w ujęciu administracyjnym - względem danego pacjenta (dłużnika administracyjnego), w rozumieniu art. 1a pkt 13 ustawy p.e.a. Z kolei organem egzekucyjnym tego obowiązku, począwszy od sierpnia 2013 r., jest właściwy wojewoda (w miejsce organów Państwowej Inspekcji Sanitarnej) ${ }^{13}$.

Wynika to bezpośrednio z istotnego i mającego wyraźny wpływ na orzecznictwo sądów administracyjnych, jak i działanie organów Państwowej Inspekcji Sanitarnej wyroku Naczelnego Sądu Administracyjnego z dnia 1 sierpnia 2013 r. Sąd ten wskazał, że (właśnie) wojewoda jest organem właściwym do prowadzenia egzekucji obowiązków o charakterze niepieniężnym (wykonania obowiązkowego szczepienia ochronnego - przyp. aut.), wynikającym zarówno z wydanych przez siebie rozstrzygnięć indywidualnych (decyzji, postanowień), jak i obowiązków

12 Dz.U. z 2017 r. poz. 1201 z późn. zm., dalej w skrócie: ustawa p.e.a.

${ }^{13}$ Istotę egzekucji administracyjnej omawia Z. Kmiecik, Postępowanie administracyjne, postępowanie egzekucyjne w administracji i postepowanie sadowoadministracyjne, wyd. 4, Warszawa 2017, s. 251-263. Szerzej także w: R. Hauser, A. Skoczylas, Postępowanie egzekucyjne w administracji. Komentarz, wyd. 8, Warszawa 2016. 
niepieniężnych wynikających z przepisów prawa (analizowanej ustawy o zapobieganiu i zwalczaniu chorób - przyp. aut. $)^{14}$.

Zgodnie z tym wyrokiem obowiązek poddania się przymusowym szczepieniom ochronnym wynika z mocy przepisów ustawowych, nie ma zatem podstawy prawnej do jego konkretyzacji w formie decyzji administracyjnej. Wynikający z przepisów obowiązek poddania dziecka szczepieniu ochronnemu jest bezpośrednio wykonalny. Jego niedochowanie aktualizuje obowiązek wszczęcia postępowania egzekucyjnego, którego rezultatem będzie poddanie dziecka szczepieniu ochronnemu. Jak wyraźnie podkreślił wskazany Sąd, obowiązek poddania dziecka szczepieniu ochronnemu jest bezpośrednio wykonalny - wynika wprost z przepisów prawa $^{15}$.

Odnosząc obserwacje do kwestii praktycznych, należy wskazać, że państwowy powiatowy inspektor sanitarny w przypadku upływu terminów wykonania obowiązku poddania się dziecka szczepieniom ochronnym (określonych przez lekarza sprawującego nad nim opiekę medyczną i znajdującego swój wyraz w dokumentacji medycznej, np. książeczce szczepień dziecka) powinien, stosownie do art. $15 \S 1$ ustawy p.e.a., wysłać osobie zobowiązanej (lub osobom zobowiązanym, tj. obojgu rodzicom jak ma to miejsce najczęściej) pisemne upomnienie zawierające wezwanie do wykonania tego obowiązku. Wynika to również z orzecznictwa sądowego ${ }^{16}$.

Upomnienie to powinno zawierać pouczenie o skierowaniu takiej sprawy na drogę postępowania egzekucyjnego w przypadku niewykonania obowiązku. Działając lege artis, organ ten, po upływie 7 dni od doręczenia upomnienia, powinien niezwłocznie skierować wniosek o wszczęcie postępowania egzekucyjnego do wojewody właściwego dla miejsca zamieszkania zobowiązanego (zobowiązanych).

14 Sygn. akt: II OSK 745/12, LEX nr 1360426.

${ }_{15}$ Podobnie prowadzące sprawy sądowo-administracyjne ze skarg obywateli: Wojewódzki Sąd Administracyjny w Bydgoszczy w wyroku z dnia 4 listopada 2015 r., II SA/ Bd 871/15, LEX nr 1948739, oraz Wojewódzki Sąd Administracyjny w Poznaniu w wyroku z dnia 27 listopada 2013 r., IV SA/Po 515/13; LEX nr 140247. Orzeczenia powyższe - powołane przykładowo, świadczą o utrwalonej linii orzecznictwa sądowego w tym zakresie.

${ }^{16}$ Jest stwierdził ww. Wojewódzki Sąd Administracyjny w Poznaniu (wyrok z dnia 27 listopada 2013 r.), postępowanie egzekucyjne ma charakter represyjny, więc wydaje się oczywiste, że jego prowadzenie w stosunku tylko do jednego z rodziców jest oczywiście niesprawiedliwe. Skierowanie upomnienia w stosunku tylko do jednego z rodziców ogranicza działanie lub może ograniczyć działanie drugiego z rodziców w zakresie realizacji obowiązku sprawowania władzy rodzicielskiej. 
Do wniosku kierowanego do wojewody, stosownie do art. $26 \S 1$ ustawy p.e.a., państwowy powiatowy inspektor sanitarny powinien dołączyć tytuł wykonawczy (wystawiony według ustalonego prawem wzoru) oraz dowód doręczenia zobowiązanemu (zobowiązanym) upomnienia.

Niewykonanie obowiązku szczepienia, pomimo zastosowania egzekucji administracyjnej, rodzi potencjalną odpowiedzialność zobowiązanych rodziców (lub rodzica) za wykroczenie, o której mowa w art. 115 $\S 1$ ustawy z dnia 20 maja 1971 r. - Kodeks wykroczeńn ${ }^{17}$. Zgodnie z tym przepisem kto, pomimo zastosowania środków egzekucji administracyjnej, nie poddaje się obowiązkowemu szczepieniu ochronnemu przeciwko gruźlicy lub innej chorobie zakaźnej albo obowiązkowemu badaniu stanu zdrowia, mającemu na celu wykrycie lub leczenie gruźlicy, choroby wenerycznej lub innej choroby zakaźnej, podlega karze grzywny do 1500 złotych albo karze nagany. Według § 2 tego artykułu tej samej karze podlega ten, kto, sprawując pieczę nad osobą małoletnią lub bezradną pomimo zastosowania środków egzekucji administracyjnej, nie poddaje jej tak określonemu szczepieniu ochronnemu lub badaniu. Odpowiedzialność tę za osobę małoletnią (dziecko) ponosi zatem opiekun (rodzic).

Sąd Najwyższy w wyroku z dnia 8 stycznia 2016 r., wydanym w wyniku rozpatrzenia kasacji wniesionej przez Rzecznika Praw Obywatelskich na korzyść obwinionego, wskazał m.in., że obowiązek rodziców poddania dziecka obowiązkowym szczepieniom ochronnym jest obowiązkiem prawnym, od którego uwolnić mogą jedynie konkretne przeciwwskazania lekarskie do szczepienia. Sąd ten wskazał także, że wynikający z przepisów obowiązek poddania dziecka szczepieniu ochronnemu jest bezpośrednio wykonalny, a jego niedochowanie aktualizuje obowiązek wszczęcia postępowania egzekucyjnego, którego zamierzonym rezultatem ma być poddanie dziecka szczepieniu ochronnemu. Zaniechanie poddania się obowiązkowemu szczepieniu - w ocenie tego Sądu - mimo zastosowania środków egzekucji administracyjnej rodzi odpowiedzialność karnoadministracyjną ${ }^{18}$.

Uiszczenie nałożonej grzywny nie jest równoznaczne z zakończeniem postępowania egzekucyjnego, gdyż ma ono na celu doprowadzenie do wypełnienia obowiązku szczepienia ochronnego. Oznacza to, że uprawniony organ może ponownie nałożyć grzywnę na opiekuna dziecka, z za-

\footnotetext{
${ }^{17}$ Dz.U. z 2015 r. poz. 1094 z późn. zm.

18 Sygn. akt: V KK 306/15, LEX nr 1963649.
} 
strzeżeniem, że grzywna nakładana wielokrotnie, zgodnie z art. $121 \S 3$ ustawy p.e.a., nie może łącznie przekroczyć kwoty 50 tys. zł.

Na marginesie rozważań należy przy tym wskazać na znaczną rolę pracowników organów Państwowej Inspekcji Sanitarnej, pracowników jednostek podległych i nadzorowanych przez Ministra Zdrowia, jak i personelu medycznego placówek zdrowotnych w kształtowaniu edukacji zdrowotnej obywateli. Skuteczne kanały przekazu wiedzy medycznej o szczepieniach ochronnych (zawierające m.in. informacje o skutkach niezaszczepienia i stosowanych szczepionkach) mogą w znacznym stopniu ograniczyć prowadzenie postępowań zarówno administracyjnych, jak i sądowych (także karnych) ${ }^{19}$.

Tytułem ilustracji problemu egzekucji obowiązku szczepień ochronnych dzieci należy wskazać na dostępne dane statystyczne. W $2014 \mathrm{r}$. w całym kraju wojewodowe wszczęli 517 postępowań egzekucyjnych w tym zakresie, a w I półroczu 2015 r. - 794 takie postępowania (liczba wniosków otrzymanych od organów PIS wynosiła - odpowiednio: 997 i 867). Liczba nałożonych grzywien $w$ celu przymuszenia (wykonania obowiązku szczepień ochronnych) w 2014 r. wyniosła 459, a w I półroczu 2015 r. 528 grzywien $^{20}$.

Pod względem skuteczności prowadzonych postępowań egzekucyjnych obowiązku szczepień ochronnych dzieci kwota nałożonych grzywien przez wojewodów w całej Polsce wyniosła w 2014 r. 175030 zł, w I półroczu 2015 r. 297555 zł. Kwota wyegzekwowanych grzywien wyniosła - odpowiednio: 23120 zł oraz 27305 zł. Liczba osób, które zrealizowały obowiązek po wszczęciu postępowania egzekucyjnego w 2014 r., wyniosła 578, a w I półroczu 2015 r. 52 osoby. Z kolei liczba osób, które pomimo wszczęcia postępowania egzekucyjnego nie zrealizowały obowiązku szczepień, wyniosła w 2014 r. 612 osób, a w I półroczu 757 osób ${ }^{21}$.

Powyższe dane świadczą o istotnym problemie społecznym, jakim jest poddawanie się obowiązkowym szczepieniom ochronnym. Istniejące rozwiązania prawne, jak i utrwalone orzecznictwo sądowe - jak wskazują

${ }^{19}$ Przykładem takich profesjonalnych działań są prowadzone przez odpowiednio: Głównego Inspektora Sanitarnego i Państwowy Zakład Higieny (Narodowy Instytut Zdrowia Publicznego) serwisy internetowe: http://www.szczepienia.gis.gov.pl [dostęp: 12.09.2017 r.] i http://szczepienia.pzh.gov.pl [dostęp: 12.09.2017 r.].

${ }^{20}$ Informacja o wynikach kontroli „System szczepień ochronnych dzieci”, Najwyższa Izba Kontroli, Warszawa 2016.

${ }^{21}$ Tamże. 
dostępne dane statystyczne, nie są wystarczającymi czynnikami wpływającymi na podejmowane przez obywateli decyzji o poddaniu się (przez dzieci) szczepieniom ochronnym.

\section{Zakończenie}

Dokonując analizy obowiązującego w naszym kraju ustawodawstwa odnoszącego się do wykonywania obowiązkowych szczepień ochronnych, należy wskazać, że przyjęte rozwiązania prawne realizują przyjętą koncepcję ochrony bezpieczeństwa zdrowotnego populacji. Znajdują one potwierdzenie w ważnych i precyzyjnych orzeczeniach sądów. Ograniczając prymat swobodnej decyzji pacjenta w kontekście podejmowania wobec niego interwencji medycznej, w przypadku szczepień ochronnych mają za zadanie stworzyć instrumentarium prawne dla skutecznej realizacji - w ten sposób definiowanych - zadań państwa w obszarze zdrowia publicznego. Oczywiście przyjęcie odmiennego principium - wolności jednostki w miejsce ochrony zdrowia zbiorowości, jest możliwe, jakkolwiek wymaga przeorientowania prowadzonej polityki zdrowotnej, której elementem jest przyjęty model organizacji systemu ochrony zdrowia. Jej wyrazem będzie w takim przypadku stosowna (ex ante) zmiana prawodawstwa.

Wszczynanie postępowań egzekucyjnych może przyczyniać się do realizacji obowiązku szczepień ochronnych. Znacznie skuteczniejsze i mniej kosztowne w skutkach społecznych jest jednak prowadzenie przez organy administracji publicznej takiej polityki zdrowotnej, która wpływając na postawy społeczne, skutecznie wyeliminuje aktualny ciągle problem nierealizowania przez obywateli szczepień obowiązkowych.

Słowa kluczowe: prawo medyczne (zdrowia publicznego), szczepienia ochronne, obowiązek prawny, egzekucja prawna, system ochrony zdrowia.

\section{Bibliografia}

Hauser R., Skoczylas A., Postępowanie egzekucyjne w administracji. Komentarz, Warszawa 2016. 
Kmiecik Z., Postępowanie administracyjne, postępowanie egzekucyjne w administracji i postępowanie sadowoadministracyjne, Warszawa 2017.

Leoński Z., Materialne prawo administracyjne, Warszawa 2009.

Wierzbowski M. (red.), Prawo administracyjne, Warszawa 2017.

Wysocki J., Czajka H., Szczepienia w pytaniach i odpowiedziach, Kraków 2010.

Informacja o wynikach kontroli System szczepień ochronnych dzieci, Najwyższa Izba Kontroli, Warszawa 2016.

Ustawa z dnia 17 czerwca 1966 r. o postępowaniu egzekucyjnym w administracji, Dz.U. z 2017 r. poz. 1201 z późn. zm.

Ustawa z dnia 14 marca 1985 r. o Państwowej Inspekcji Sanitarnej, Dz.U. z 2017 r. poz. 1261.

Ustawa z dnia 6 listopada 2008 r. o prawach pacjenta i Rzeczniku Praw Pacjenta, Dz.U. z 2017 r. poz. 1318 z późn. zm.

Ustawa z dnia 5 grudnia 2008 r. o zapobieganiu oraz zwalczaniu zakażeń i chorób zakaźnych u ludzi, Dz.U. z 2016 r. poz. 1866 z późn. zm.

\section{IMPLEMENTATION OF PREVENTIVE VACCINES - LEGAL IMPLICATIONS}

\section{S u m m a r y}

The article presents an overview of selected legal solutions in Poland - in the field of preventive vaccination, considered as an important element to ensure the health security of people vaccinated as well as the entire population. Analysis of existing legislation and jurisprudence, qualified under medical law, is backed up with available statistical data and practical observations from the author's professional experience. Presented issues are seen from the perspective of the patient and his safety as a public health category. This area of responsibility of the state is of particular importance for shaping patient attitudes, approving or denying vaccination. This is especially true of parents' attitudes towards vaccination of children.

Key words: medical law (public health law), preventive vaccination, legal obligation, legal enforcement, health care system.

\section{ВНЕДРЕНИЕ ОХРАННОЙ ВАКЦИНАЦИИ - ЮРИДИЧЕСКИЕ ПОСДЕДСТВИЯ}

P е 3 юо е

Статья представляет обзор избранных правовых решений в области профилактических вакцинаций, признанных как существенный элемент 
обеспечения безопасности для здоровья лиц, которые подпадают к вакцинации, как и целой популяции. Анализ законодательства и судебных вынесенных решений, которое квадифицируется в рамках медицинского права, проведен на основании доступных статистических данных и практических наблюдений, возникших из профессионального опыта Автора. Представленные вопросы представлены со стороны пациента и его безопасности, как категории публичного здоровья. Данная область ответственности государства имеет особенное значение для формирования подожения пациентов, одобряющих или отрицающих профилактических вакцинаций. Это касается, прежде всего, положения родителей относительно вакцинации детей.

Ключевые слова: медицинское право (публичное здоровье), профилактическая вакцинация, юридическое обязательство, правовое исполнение, система здравоохранения. 